\title{
Flexible Multiple Micro Sensor for Local Persistent Effect Test in High Temperature Proton Exchange Membrane Fuel Cell Stack
}

\author{
Chi-Yuan Lee*, Fang-Bor Weng, Chuang-Yu Hsieh, Ay Su, Fan-Hsuan Liu, Chih-Kai Cheng, \\ Yi-Chang Shiu
}

Department of Mechanical Engineering, Yuan Ze Fuel Cell Center, Yuan Ze University, Taoyuan, Taiwan, R.O.C.

*E-mail: cylee@saturn.yzu.edu.tw

doi: $10.20964 / 2017.06 .14$

Received: 5 March 2017 / Accepted: 3 April 2017 / Published: 12 May 2017

The nonuniformity of local temperature, voltage and current in the high temperature proton exchange membrane fuel cell stack can accelerate the aging of membrane electrode assembly (MEA) and the failure of overall fuel cell stack. This study used micro-electro-mechanical systems (MEMS) technology to integrate micro temperature, voltage and current sensors into a $40 \mu \mathrm{m}$ thick stainless steel substrate, the flexible multiple micro sensor was embedded in the high temperature fuel cell stack for 100-hour persistent effect test at $150^{\circ} \mathrm{C}$ operating temperature and constant current $20 \mathrm{~A}$ and real-time microscopic diagnosis of local information of internal temperature, voltage and current. The experimental results showed that the nonuniform temperature distribution in the high temperature fuel cell stack resulted in nonuniform voltage and current distributions and hot stack.

Keywords: High temperature proton exchange membrane fuel cell stack, MEMS, Flexible multiple micro sensor, 100-hour persistent effect test, real-time microscopic diagnosis.

\section{$\underline{\text { FULL TEXT }}$}

(C) 2017 The Authors. Published by ESG (www.electrochemsci.org). This article is an open access article distributed under the terms and conditions of the Creative Commons Attribution license (http://creativecommons.org/licenses/by/4.0/). 